\title{
ANALYSIS OF THE BEARING NODES LOADS OF TURBINE ENGINE AT AN UNMANNED HELICOPTER DURING A JUMP UP AND JUMP DOWN MANEUVER
}

\section{ANALIZA OBCIĄŻEŃ WĘZŁÓW ŁOŻYSKOWYCH SILNIKA TURBINOWEGO W BEZZAŁOGOWYM ŚMIG ŁOWCU PODCZAS MANEWRU SKOK W GÓRĘ I SKOKW DÓŁ*}

\begin{abstract}
The article is part of the work, which was made to systematize the operating conditions of bearing loads in the rotor assembly of FSTC-1 turbine engine, which is designed in the Department of Thermodynamics, Fluid Mechanics and Aviation Propulsion Systems at Lublin University of Technology. This engine assumes the use of the gas bearing in compressor drive unit to improve the operating characteristics. This is justified by difficult working conditions associated with high speeds, high temperatures and difficult access, as in the case of gas bearings is not a major problem. A mathematical model of possible states of load bearing nodes in compressor drive unit was also presented. Load analysis was carried out for maneuver jump up and jump down based on the time course of geometric altitude from the radio altimeter based on real tests of a manned PZL W3-Sokol helicopter. The dependence of the altitude changing during the time was approximated by the least squares method and then the velocity and acceleration changes were determined. On this basis, the forces acting on the bearing in compressor drive unit under static and dynamic conditions were calculated. These values will be confronted with the values obtained during other maneuvers, and will be used as input assumptions to project of the gas bearings.
\end{abstract}

Keywords: gas bearings, helicopters, turbine engines.

\begin{abstract}
Artykut stanowi część prac, w których dokonano usystematyzowania eksploatacyjnych stanów obciażeń łożysk zespolu wirnikowego silnika turbinowego FSTC-1, który projektowany jest w Katedrze Termodynamiki, Mechaniki Ptynów i Napędów Lotniczych na Politechnice Lubelskiej. Silnik ten zakłada zastosowanie w zespole wytwornicowym łożysk gazowych w celu poprawy właściwości eksploatacyjnych. Jest to uzasadnione trudnymi warunkami pracy zwiazanymi z dużymi prędkościami obrotowymi, wysokimi temperaturami oraz trudnym dostępem, co w przypadku łożysk gazowych nie stanowi większego problemu. Przedstawiono równiė matematyczny model możliwych do wystapienia stanów obciązeń węzłów tożyskowych zespołu wytwornicowego. Analizę obciażeń przeprowadzono dla manewru skok w górę i skok $w$ dót na podstawie przebiegu czasowego wysokości geometrycznej z radiowysokościomierza w oparciu o rzeczywiste badania załogowego śmigłowca PZL W3-Sokót. Zależność zmiany wysokości w czasie aproksymowano metoda najmniejszych kwadratów a następnie wyznaczono dla niej zmiany prędkości oraz przyspieszeń. Na tej podstawie wyznaczono wartości sit działajace na tożyska zespołu wytwornicowego w warunkach statycznych jak $i$ dynamicznych. Wartości te zostana skonfrontowane z wartościami uzyskanymi podczas innych manewrów oraz postuża, jako założenia wejściowe do projektu tożysk gazowych.
\end{abstract}

Stowa kluczowe: tożyska gazowe, śmigłowce, silniki turbinowe.

\section{Introduction}

Gas bearings are used in many types of rotating machines such as turbochargers, turbine engines or high-speed electro tools e.g. grinding machines. Such a bearings have many advantages as compared to conventional bearings, which include mainly resistance to thermal loads, high speeds, very small friction value, high durability, susceptibility, the ability to damp vibrations, impact resistance (foil gas bearing) and stable operation at high speeds. Gas bearings are currently mostly used in the temperature range up to $300^{\circ} \mathrm{C}$ and cryogenic applications. However, the highest operating temperature that was observed by [5], amounts to $815^{\circ} \mathrm{C}$. Operating temperature of foil gas bearings depends directly on the used materials and sliding coatings. The most common coatings are formed with polymer materials which protect the sliding foil surface against wear [5]. However, load capacity of gas bearing, is even worse, so it's important to use rotating assembly with normal overloads. Properties of gas bearings including a foil gas bearings are described in several studies based on the experimental works $[7,8,12]$. There are many mathematical models and studies describing the operation of the bearings, including the thermal-hydrodynamic analysis like [14], where the established mathematical models can be used to design more advanced foil bearings, in particular foil bearings with variable axial stiffness. Interest of gas bearing is very high, but it should be remembered that the bearing assembly design process requires knowledge of the applications of your device and especially the knowledge of the dynamic conditions during the operation. The article describes the state of the bearing node in turbine engine to power an unmanned helicopter with the take-off mass up to $100 \mathrm{~kg}$.

Turbine engines are still a competition with piston engines in aerospace applications. By Dudziak [1], mass of the turbine engine assembly, including fuel, is significantly less than the mass of the assembly with a piston engine in the case of one hour flight and the difference of the mass decreases with increasing operation time. This is due to the fact that the turbine engines have a specific fuel consumption of $0.4-0.7 \mathrm{~kg} / \mathrm{kWh}$ while piston engines has $0.35 \mathrm{~kg} / \mathrm{kWh}$. However, to

\footnotetext{
(*) Tekst artykułu w polskiej wersji językowej dostępny w elektronicznym wydaniu kwartalnika na stronie www.ein.org.pl
} 
power the unmanned aerial vehicles, including light helicopters that perform missions lasting about 1-2 hours, more profitable it becomes to use a turbine engine. Cost-effectiveness of the use of turbine engines is increasing even more due to differences in fuel prices. In the case of Lublin Airport EPLB, price per liter of Avgas 100LL aviation gasoline without excise duty, currently is an average of 7.18 PLN, while a liter of Jet A-1 aviation kerosene costs 2.69 PLN. But on other hand the piston engines are much more eco-friendly in comparison with the turbine engines [17], especially according to the diesel engines [13].

In Poland and all over the world people are working on unmanned aircraft including the unmanned helicopters. An example of two helicopters, of which one is a construction based on SW-4 helicopter from PZL Swidnik S.A., while the second is ILX-27 developed by the Institute of Aviation, Air Force Institute of Technology and Military Aviation Company No. 1 in Lodz [4, 6]. In the ILX-27 helicopter, a piston engine Lycoming 0-540-F1B5 is used with a power of $191 \mathrm{~kW}$ (260hp), which gives the mass/power ratio with a maximum mass a helicopter equal to $4.23 \mathrm{~kg} / \mathrm{hp}$. In addition to the higher value of mass to power ratio, another disadvantage of piston engines are also the vibrations, but in the 6-cylinder F1B5 drive unit, vibration level is relatively low. In the case of the RUAV Solo helicopter by PZL-Swidnik construction, drive unit represents a turbine engine, Rolls-Royce 250-C20R/2 with a power of $457 \mathrm{hp}(336 \mathrm{~kW})$.

Helicopters completing missions are often in such flight conditions, in which the rotor, tail rotor, the hull structure and drive components (including the drive engines), and also bearing nodes of rotor assembly of engines are exposed to considerable loads. These states are the result of extreme flight maneuvers from flight scenario or either from the changing environmental conditions of flight. In addition, rapidly changing flight parameters in such maneuvers cause an intense change in the parameters, accordingly to engines actions to achieve the engine limit states [2].

During the operation of the helicopter, on the bearings of rotor assembly of turbine engine, in addition to high speeds of several tens of thousands rpm, the forces resulting from the kinematic motion of the helicopter and flow processes occurring in the engine are also acting. These forces create state changes, which are characterized by difficult to establish design values. This article attempts to systematize states and causes of operational loads and shows how to simulate such work conditions depending on operating conditions. Causes of bearing loads of rotor assembly, according to [3] can be divided into two main groups

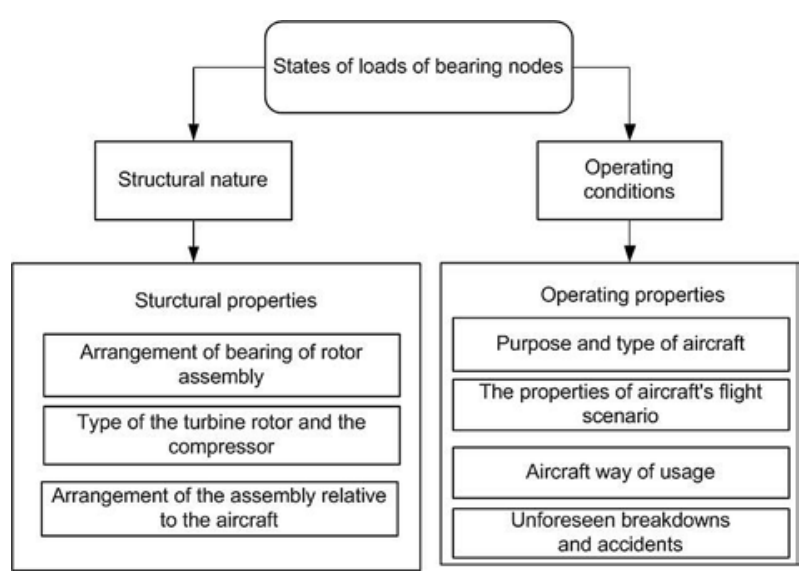

Fig. 1. Scheme to systematize the causes of the load in the compressor drive unit in the rotor assembly of turbine engine [7] shown in Figure1. The first are the causes of structural nature, resulting from the design features of the engine rotor assembly and its mounting on the aircraft, while the second reasons stems from the course and nature of the operation (operating conditions).

From the analysis of the operating conditions of helicopters, including military helicopters operating conditions, and helicopters form the [3], it can be deduced that some insights allows to systematize the causes of the load in the compressor drive unit of the rotor assembly of turbine engine as follows:

- states of load resulting from the profile operation of the aircraft that was established by the manufacturer,

- states resulting from the failure or air accident without engine destroying - these conditions can be considered like extreme for failure-free operation of bearing in rotor assembly,

- states resulting from extreme helicopter flights while performing different maneuvers (acrobatic maneuvers, combat flying).

These observations allow to create simulation model of rotor assembly with bearing nodes.

\section{Research object}

One turbine engines designed in the Department of Thermodynamics, Fluid Mechanics and Aviation Propulsion Systems in the Lublin University of Technology requires the use the gas bearings in bearing nodes in compressor drive unit. This engine is shown in Figure 2, together with the basic parameters in the Table 1.

The use of gas bearings in illustrated engine is necessary to improve performance characteristics. However, this only applies to the bearing nodes in compressor drive unit shaft. This is justified by difficult working conditions (high speed, high temperatures and difficult

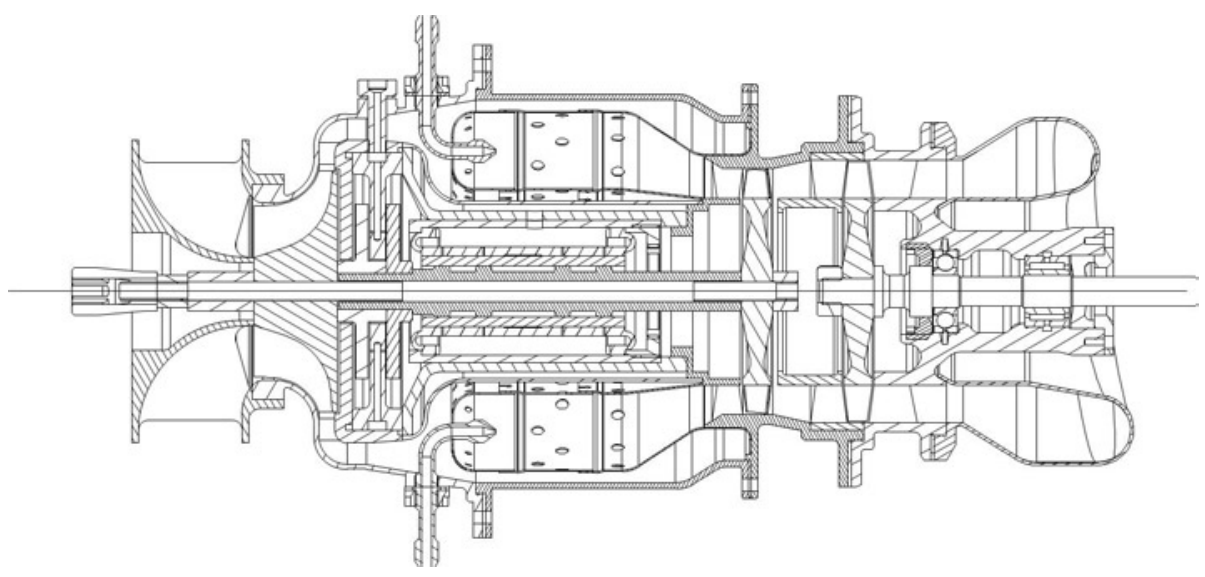

Fig. 2. FSTC-1turbine engine with a power takeoff on shaft, own study

Table 1. Basic parameters of FSTC-1 engine

\begin{tabular}{||l|c|}
\hline \multicolumn{2}{|c|}{ FSTC-1 engine parameters } \\
\hline Calculated effective power Ne [kW] & 18 \\
\hline Rotation frequency of compressor drive unit turbine nTW [rmp] & 96000 \\
\hline Rotation frequency of drive turbine nTN [rpm] & 60000 \\
\hline Compressor compression ratio & 3 \\
\hline Air mass flow rate mp [kg/s] & 0.256 \\
\hline Fuel consumption per seconds Bs [kg/s] & 0.003 \\
\hline
\end{tabular}

access), which in the case of gas bearing is permissible $[9,11,15,16]$. Compressor drive unit, which was analyzed, is schematically shown in Figure3. It consists of a shaft on which the axial radial compressor rotor and turbine axis rotor were positioned. All of the structure is mounted on two radial and one axial gas bearings. Gas bearings 
are mounted inside (between the compressor and the turbine), but the radial bearing trunnions are the fragments of the shaft and the thrust disc of axial bearings is connected with the shaft. The analysis assumed that the engine is arranged longitudinally in a helicopter and states of bearing loads depend on the flight scenario and the way of flight, where several cases of operation of the helicopter were distinguished.

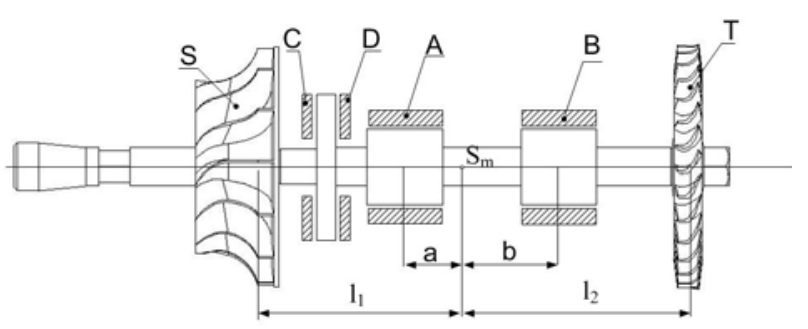

Fig. 3. Schematic model of a compressor drive unit rotor assembly, including a system of sliding bearings. A, B-radical bearing bush, $C, D$-axial bearing thrust disc, S- compressor, T- turbine, own study based on [7] combat helicopters on the battlefield and normally used in an attack using such covers like vertical deflection behind the wall (which can be a forest, building etc.) and then lunching a missile and hide behind the cover. It requires a high precision (it determines the accuracy of shots etc.), but also a relatively short period of time for maneuver implementation to avoid shouting down by the lurking enemy.

The analyzed maneuver begins by hovers at a height of $3.05 \mathrm{~m}$, and then the helicopter rises to the desired height in the range of $12.2-15.2 \mathrm{~m}$ (fig. 4). For a fixed altitude, the helicopter hovers for at least 2 seconds for lunching the missile at the target, and then drops to a predetermined altitude $3.05 \mathrm{~m} \mathrm{[10]}$.

The analysis was carried out taking into account the time course of geometric height from a radio altimeter. The maneuver was divided into two parts: the ascent and descent. From publication [10], the coordinates put in the table 2 was imported. Coordinates were approximated by the least squares method, what gives the following five-degree polynomial function. The degree of the polynomial is conditional on receiving the best quality data.

Polynomial function describing the change in altitude during time

\section{Analysis of the load states of drive assembly during a jump up and jump down maneuver}

State model of bearing loads based on actual values obtained from the analysis of flight data from helicopter PZL W-3 Sokol. Despite the size difference it was assumed that the unmanned helicopter equipped with a designed engine will be able to perform missions with such flight scenario like bigger helicopter. The analysis of acceleration, which the rotor assembly of designed engine is subjected, was carried out based on the results of experimental studies of the behavior of the helicopter W-3 Sokol in flight NOE [10]. Helicopters, especially unmanned versions must perform certain combat tasks such as, observation of the enemy, the discharge of the explosive materials or taking a shot at his maneuverability in the sufficient way to avoid possible shootout. These maneuvers enable to achieve it targets suffi-

Table 2. Coordinates of the altitude changes depending on the time for maneuver jump up during the rising

ciently. It is assumed that the helicopter does not take air combat. This analysis is sufficient due to the lack of experimental data relating to the behavior of unmanned helicopters in extreme flying.

The most common maneuvers that occur during the execution of the flight mission by unmanned helicopters may include the following: jump up and jump down, acceleration and deceleration, braking before the attack, tight curve and return to the target. From the five maneuvers listed in this article, it was decided to analyze the maneuver jump up and jump down, which is shown in Figure4.

Jump up and jump down allows, among other things, checking the vertical damping, i.e. the ability to accurate vertical acceleration and deceleration, and at the same time for the actual time estimation of this maneuvers, and with the given speeds, for the calculation of acceleration acting on the tested system. It is a maneuver often used by
$H=f(t)$ for the raising during the maneuver jump up is described by equation (1), while (2) and (3) are respectively from first degree derivative (speed) and second degree derivative (acceleration):

$$
\begin{aligned}
H & =f(t)=0.0720438301538917 \mathrm{x}^{5}+0.072043830153892 \mathrm{x}^{4} \\
& +20.9743333138697 \mathrm{x}^{3}-106.48692542687 \mathrm{x}^{2} \\
& +262.855196462725 \mathrm{x}^{1}-252.639998086681 \mathrm{x}^{0}
\end{aligned}
$$

$$
\begin{aligned}
V & =\frac{\partial H}{\partial t}=5 \cdot 0.07204383015389 \mathrm{x}^{4}+4 \cdot 0.07204383015389 \mathrm{x}^{3} \\
& +3 \cdot 20.974333313869 \mathrm{x}^{2}+2 \cdot(-106.486925427) \mathrm{x}^{1} \\
& +262.855196462725 \mathrm{x}^{0}
\end{aligned}
$$

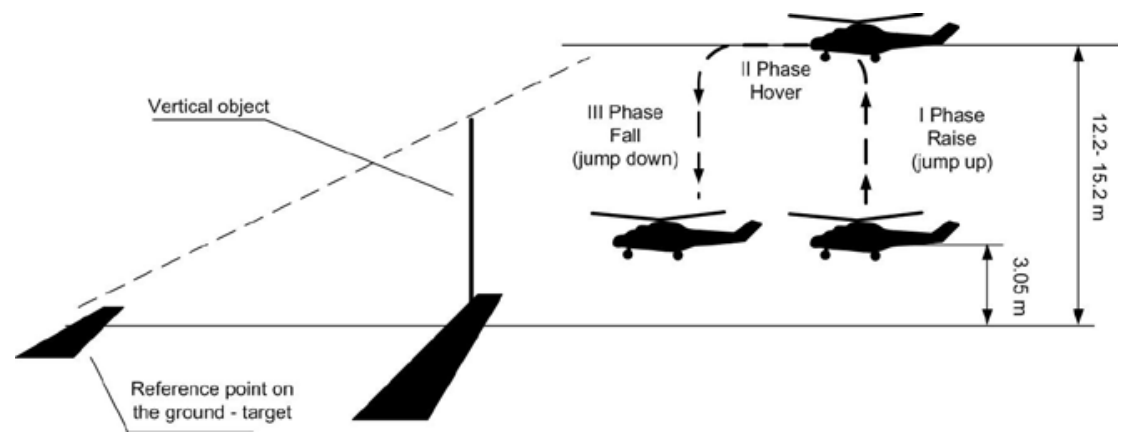

Fig. 4. Scheme of maneuver jump up and jump down, own study based on [10]

$$
\begin{aligned}
\mathrm{a}= & \frac{\partial \mathrm{V}}{\partial \mathrm{t}}=20 \cdot 0.07204383015389 \mathrm{x}^{3}+12 \cdot 0.0720438301539 \mathrm{x}^{2} \\
& +6 \cdot 20.97433331387 \mathrm{x}^{1}+2 \cdot(-106.48692542687) \mathrm{x}^{0}
\end{aligned}
$$

Figure 5 shows the function created with measuring points and function approximating form the altitude of the helicopter PZL W-3 Sokol flight depending on the time during a maneuver jump up. Figures 6 and 7 show a change in climbing speed and acceleration of the helicopter. 


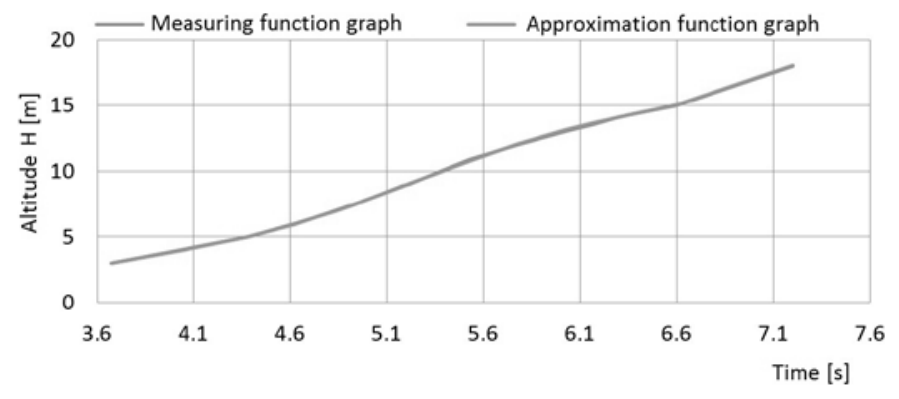

Fig. 5. Measurement and approximating functions form the altitude of the helicopter PZL W-3 Sokol flight depending on the time during a maneuver jump up

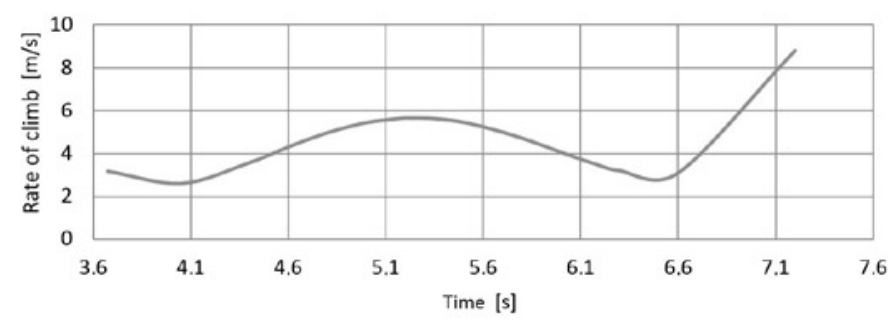

Fig. 6. Change in climbing speed of helicopter W-3 Sokol for maneuver jump up

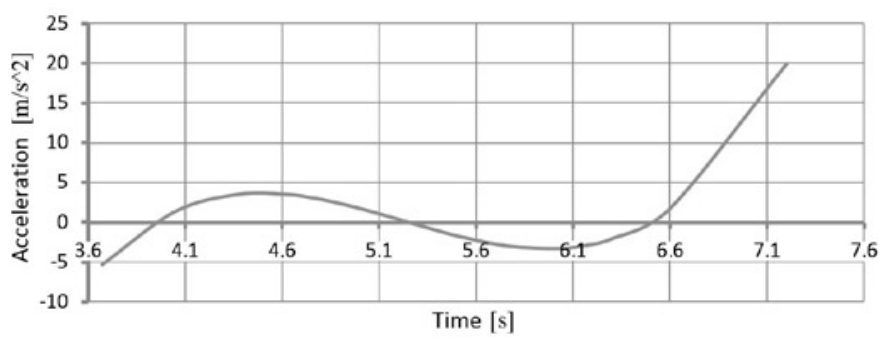

Fig. 7. Change in climbing acceleration of helicopter W-3 Sokol for maneuver jump up

Table 2. Coordinates of the altitude changes depending on the time for maneuver jump up during the rising

\begin{tabular}{|c|c|c|c|c|c||}
\hline No. & $\begin{array}{c}\text { Time } \\
{[\mathrm{s}]}\end{array}$ & $\begin{array}{c}\text { Registered alti- } \\
\text { tude }[\mathrm{m}]\end{array}$ & No. & $\begin{array}{c}\text { Time } \\
{[\mathrm{s}]}\end{array}$ & $\begin{array}{c}\text { Registered alti- } \\
\text { tude }[\mathrm{m}]\end{array}$ \\
\hline 1 & 3.68 & 3.00 & 10 & 5.22 & 9.00 \\
\hline 2 & 4.05 & 4.05 & 11 & 5.36 & 9.90 \\
\hline 3 & 4.38 & 5.00 & 12 & 5.53 & 10.89 \\
\hline 4 & 4.63 & 6.00 & 13 & 5.77 & 12.00 \\
\hline 5 & 4.75 & 6.58 & 14 & 6.03 & 13.05 \\
\hline 6 & 4.82 & 6.95 & 15 & 6.17 & 13.57 \\
\hline 7 & 4.92 & 7.47 & 16 & 6.30 & 14.10 \\
\hline 8 & 5.03 & 8.00 & 17 & 6.60 & 15.00 \\
\hline 9 & 5.18 & 8.89 & 18 & 7.20 & 18.00 \\
\hline
\end{tabular}

The coordinates given in table 3 were approximated by the least squares function described below, what gives the following five-degree polynomial function. The degree of the polynomial is conditional on receiving the best quality data.

Polynomial function describing the change in altitude during time $\mathrm{H}=\mathrm{f}(\mathrm{t})$ for the falling during the maneuver jump down:
$H=f(t)=-0.0625269149733026 x^{5}+3.72504261903523 x^{4}-88.0177032174416 x^{3}$

$+1030.67671304047 \mathrm{x}^{2}-5982.84455547936 \mathrm{x}^{1}+13798.715321263 \mathrm{x}^{0}$

$V=\frac{\partial H}{\partial t}=5 \cdot(-0.06252691497330) \mathrm{x}^{4}+4 \cdot 3.725042619035 \mathrm{x}^{3}$

$+3 \cdot(-8.0177032174416) \mathrm{x}^{2}+2 \cdot 1030.676713040 \mathrm{x}^{1}-5982.84455547936 \mathrm{x}^{0}$

$$
\begin{aligned}
\mathrm{a} & =\frac{\partial \mathrm{V}}{\partial \mathrm{t}}=20 \cdot(-0.0625269149733) \mathrm{x}^{3}+12 \cdot 3.72504261903 \mathrm{x}^{2} \\
& +6 \cdot(-88.017703217441) \mathrm{x}^{1}+2 \cdot 1030.676713040 \mathrm{x}^{0}
\end{aligned}
$$

Figure 8 shows the function created with measuring points and function approximating form the altitude of the helicopter PZL W-3 Sokol flight depending on the time during a maneuver jump down. Figures 9 and 10 show a change in climbing speed and acceleration of the helicopter.

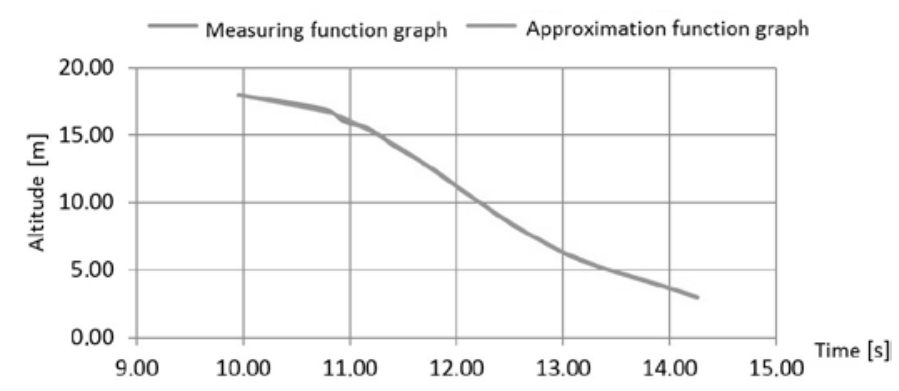

Fig. 8. Measurement and approximating functions form the altitude of the helicopter PZL W-3 Sokol flight depending on the time during a maneuver jump down

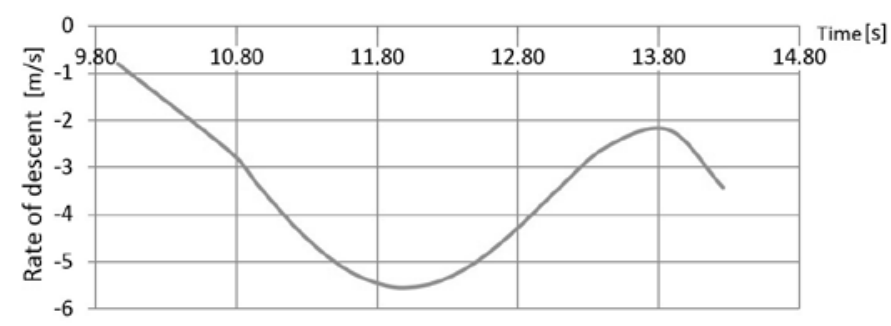

Fig. 9. Change in climbing speed of helicopter $W$-3 Sokol for maneuver jump down

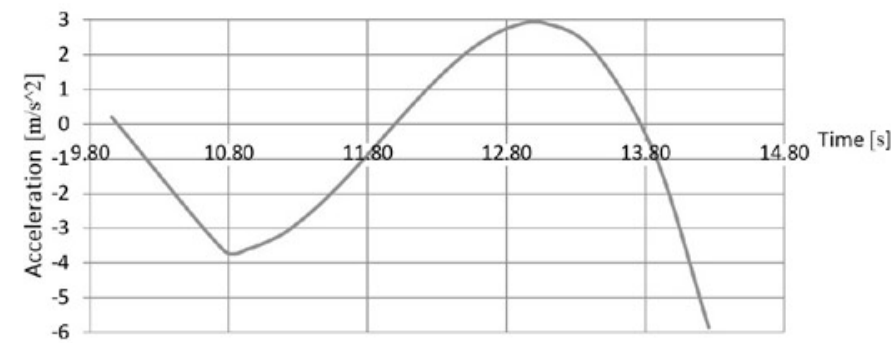

Fig. 10. Change in climbing acceleration of helicopter W-3 Sokol for maneuver jump down

\section{The states model of loads of the gas bearing}

The functioning of the nodes loads of the gas bearing was described in accordance with [7] equations for different types of forces in Cartesian system (fig. 11). In order to generalize the discussion, dimen- 
a)

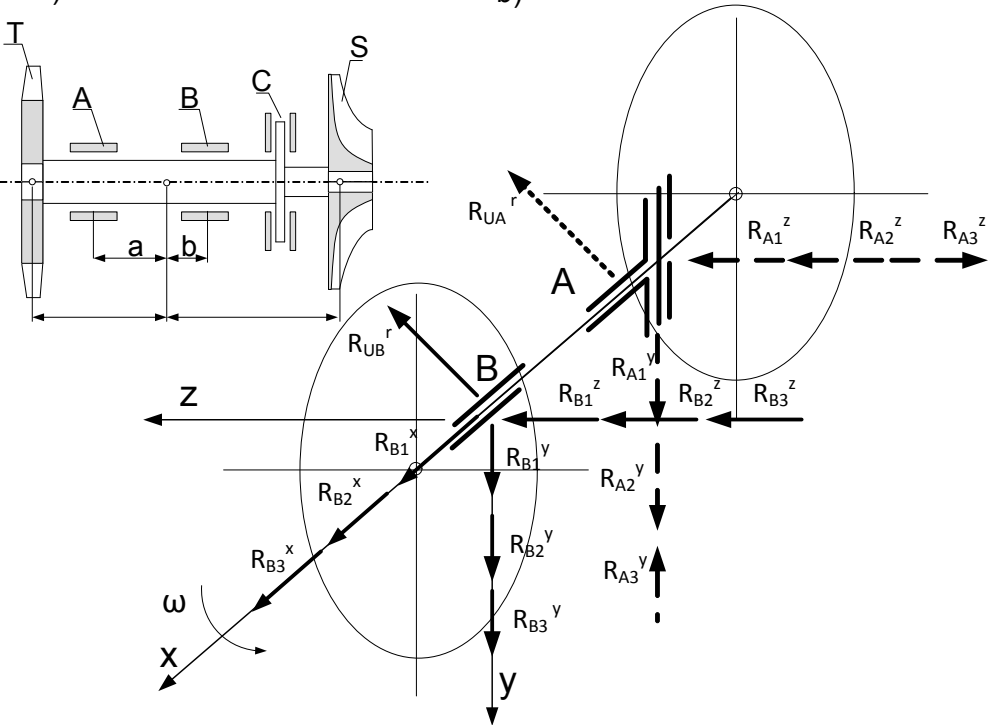

Fig. 11. Schematic model of rotor assembly with bearing nodes, a-geometric model of assembly, b-state diagram of bearing loads of assembly, own study based on [3] sionless forces forms were used (with respect to gravity of the system). A list of equations that describe the forces of loads of bearing nodes in rotor assembly are contained in table 4 .

\section{Loads of bearing nodes of rotor assembly under static conditions.}

Radial bearings are subjected to static forces of gravity derived from each of the components of rotor assembly which are connected to the shaft. All these elements of compressor drive

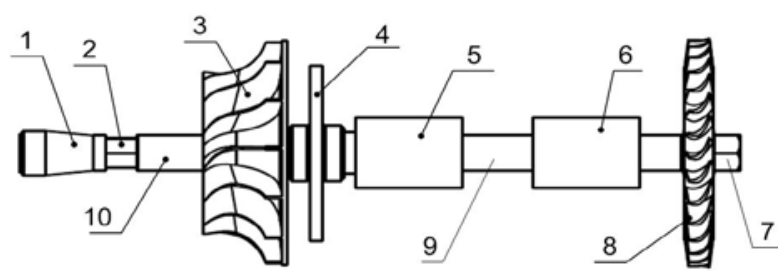

Fig. 12. Diagram showing the components of compressor drive unit rotor assembly of the turbine engine, 1- clamping sleeve with the internal splines, 2- clamping nut from rotor compressor, 3- compressor rotor, 4- thrust disc of axial bearing, 5, 6-radical bearing sleeve, 7- clamping nut from rotor of compressor drive unit turbine, 8- rotor of compressor drive unit turbine, 9- compressor drive unit shaft, 10- compressor rotor sleeve, own study.

Table 4. A list of equations that describe the forces of loads of bearing nodes in rotor assembly [3].

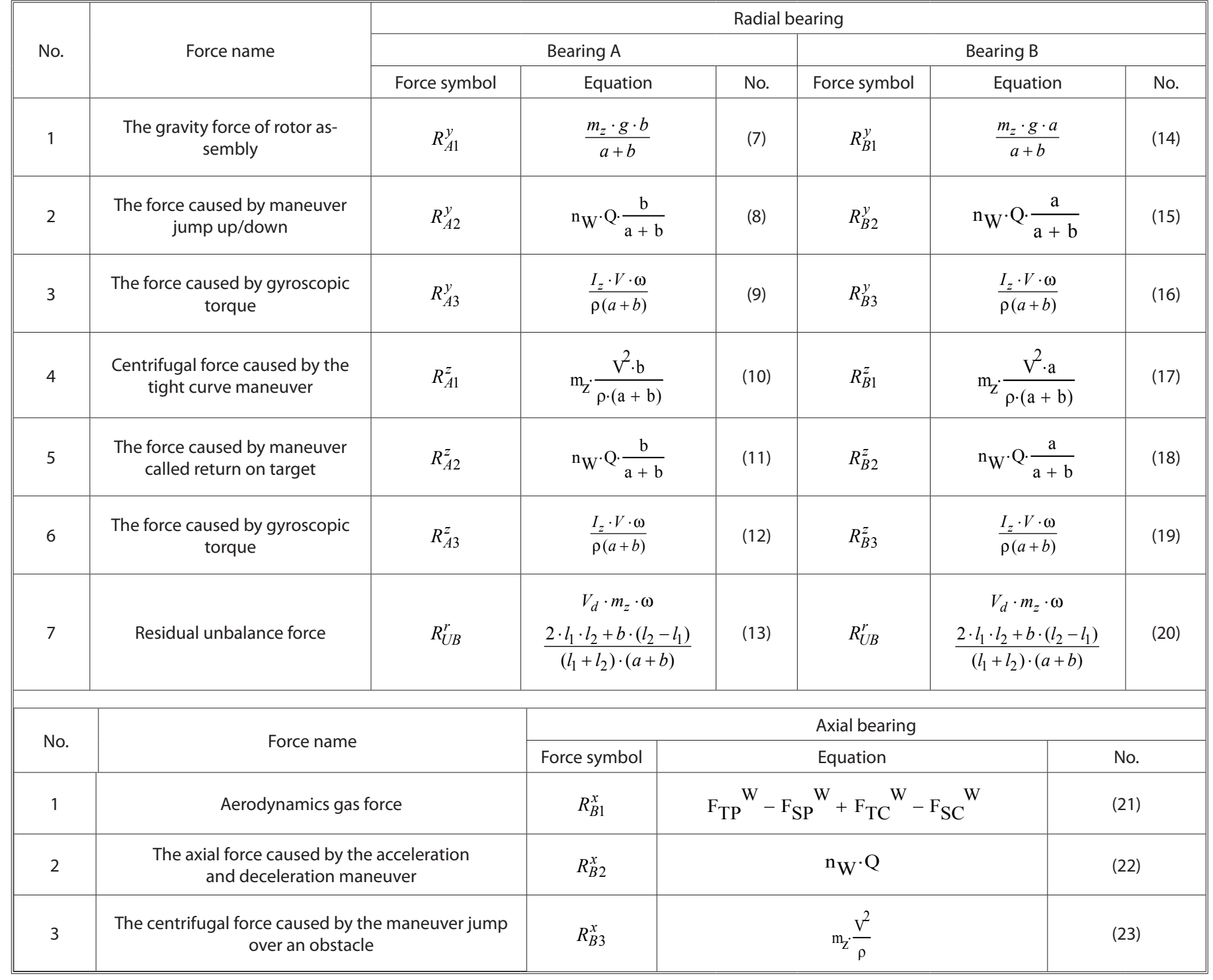


Table 5. Basic parameters of the components of compressor drive unit rotor assembly

\begin{tabular}{|c|c|c|c|c|c|}
\hline No. & Element name & Material & Volume $\left[\mathrm{m}^{3}\right]$ & Mass [kg] & Weight $[\mathrm{N}]$ \\
\hline 1 & Clamping sleeve with the internal splines & Titanium & $2.644 \mathrm{e}-6$ & 0.012 & 0.118 \\
\hline 2 & Clamping nut from rotor compressor & Steel & $6.761 e-7$ & 0.005 & 0.049 \\
\hline 3 & Compressor rotor & Titanium & $3.413 e-5$ & 0.152 & 1.491 \\
\hline 4 & Thrust disc of axial bearing & Steel & $1.325 \mathrm{e}-5$ & 0.104 & 1.020 \\
\hline 5,6 & Radical bearing sleeve & Steel & $0.843 e-5$ & 0.067 & 0.657 \\
\hline 7 & Clamping nut from rotor of compressor drive unit & Steel & $8.284 \mathrm{e}-7$ & 0.007 & 0.069 \\
\hline 8 & Rotor of compressor drive unit turbine & Steel & $2.091 \mathrm{e}-5$ & 0.164 & 1.609 \\
\hline 9 & Compressor drive unit shaft & Steel & $1.824 \mathrm{e}-5$ & 0.143 & 1.400 \\
\hline 10 & Compressor rotor sleeve & Titanium & $1.763 e-6$ & 0.008 & 0.079 \\
\hline
\end{tabular}

Density of used materials: steel, density $=7860 \mathrm{~kg} / \mathrm{m}^{3} ;$ titanium, density $=4460 \mathrm{~kg} / \mathrm{m}^{3}$

unit rotor assembly are determined and parameterized in Figure12 and in table 5 .

The components weight as indicated in table 5 determines the formation of the forces acting on the radical bearing. The method of calculation is shown below.

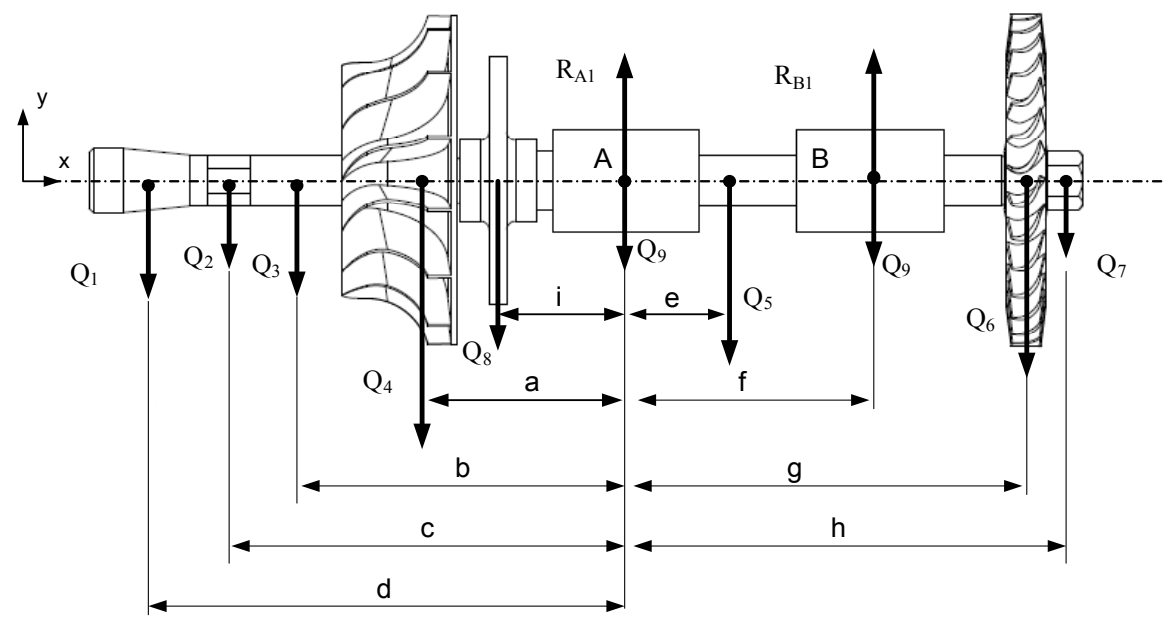

Fig. 13. Forces acting on radial bearings. Forces names as given in the tables 5 and 6, own study

Table 6. Distance between the gravity center of individual elements from the rotor assembly and the bearing node A (see Fig. 13)

\begin{tabular}{|c|c|c|c|c|c||}
\hline \hline Distance name & $\begin{array}{c}\text { Length } \\
{[\mathrm{mm}]}\end{array}$ & Distance name & $\begin{array}{c}\text { Length } \\
{[\mathrm{mm}]}\end{array}$ & Distance name & $\begin{array}{c}\text { Length } \\
{[\mathrm{mm}]}\end{array}$ \\
\hline $\mathrm{a}$ & 46.29 & $\mathrm{~d}$ & 110.07 & $\mathrm{~g}$ & 91.42 \\
\hline $\mathrm{b}$ & 75.38 & $\mathrm{e}$ & 16.42 & $\mathrm{~h}$ & 100.51 \\
\hline $\mathrm{c}$ & 90.21 & $\mathrm{f}$ & 56.00 & $\mathrm{i}$ & 29.50 \\
\hline
\end{tabular}


The values of the reaction forces acting on the bearing nodes has been determined from the equation of forces sum on the $\mathrm{y}$ axis and the equations of torque sum with respect to A point, what is presented below:

$$
\begin{aligned}
& \sum P_{i y}=R_{A 1}+R_{B 1}-Q_{1}-Q_{2}-Q_{3}-Q_{4}-Q_{5}-Q_{6}-Q_{7}-Q_{8}-Q_{9}-Q_{9}=0 \\
& \sum M_{i A}=Q_{8} \cdot i+Q_{4} \cdot a+Q_{3} \cdot b+Q_{2} \cdot c+Q_{1} \cdot d-Q_{5} \cdot e+R_{B 1} \cdot f-Q_{6} \cdot g-Q_{7} \cdot h-Q_{9} \cdot f=0
\end{aligned}
$$

$R_{B 1}=\left(-Q_{8} \cdot i-Q_{4} \cdot a-Q_{3} \cdot b-Q_{2} \cdot c-Q_{1} \cdot d+Q_{5} \cdot e+Q_{6} \cdot g+Q_{7} \cdot h+Q_{9} \cdot f\right) / f$

$R_{A 1}=\left(-\left(-Q_{8} \cdot i-Q_{4} \cdot a-Q_{3} \cdot b-Q_{2} \cdot c-Q_{1} \cdot d+Q_{5} \cdot e+Q_{6} \cdot g+Q_{7} \cdot h+Q_{9} \cdot f\right) / f\right)+$

$$
Q_{1}+Q_{2}+Q_{3}+Q_{4}+Q_{5}+Q_{6}+Q_{7}+Q_{8}+Q_{9}+Q_{9}
$$

$$
\begin{aligned}
& P_{A 1}^{s t}=R_{A 1}=5.638 N \\
& P_{B 1}^{s t}=R_{B 1}=1.631 N
\end{aligned}
$$

According to Newton's third law of motion, if the bearing pan acts on the shaft with the force $\mathrm{P}_{\mathrm{A} 1}$ (acting force), the shaft is acting on the pan with the reacting force $\mathrm{R}_{\mathrm{A} 1}$, with the same magnitude but opposite direction (fig. 14).

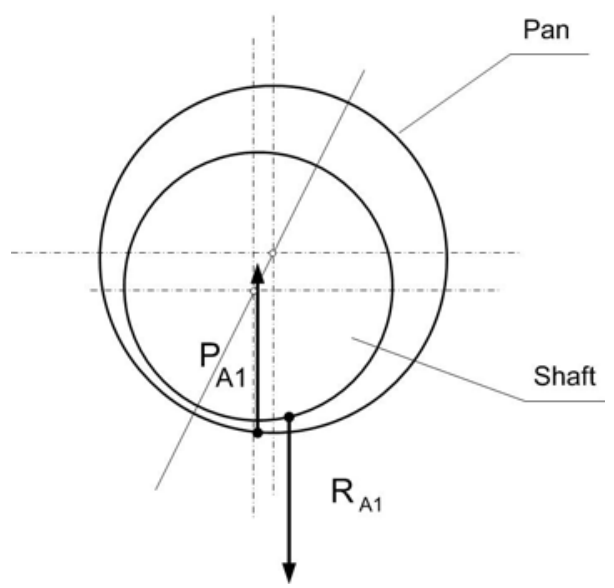

Fig. 14. Scheme of each other interaction between pan and shaft. $P_{A 1}-$ force that pan is acting the shaft, $R_{A 1}$-reaction force from $P_{A 1}$ force, own study

Reaction values indicate greater load in A bearing, which is a consequence of the position of the mass center closer to that node. Already at this stage we can assume, that the calculations will be carried out taking into account the A bearing, because it is more exposed to possible damage.

\section{Loads of bearing nodes of rotor assembly under dynamic conditions.}

On the rotor assembly in addition to static forces (non time-varying values) also dynamic loads operates. While in the first case, there are only fixed values, directions and points of forces application, in dynamic loading there is the situation in which external and inertia forces due to accelerations arising from the mass of the body are acting on the body. The overload magnitude is dependent mainly on the acceleration and in extreme states it can load and unload the tested bearings.
The purpose of the analysis of dynamic loads of bearing in rotor assembly is to determine such $k$ coefficient, depending on the maximum acceleration values, that guarantee correct operation of the bearings in the tested range of loads:

$$
P_{A 1}^{d y n}=k \cdot P_{A 1}^{s t}=k \cdot g \cdot \sum m_{i}
$$

where:

$P_{A 1}^{d y n}-$ dynamic force acting on bearing,

$g \quad$ - gravity acceleration $(9,81$ value was chosen for the calculation),

$k-$ the overload value, the ratio of acceleration experienced during the flight $g_{\text {zast }}$ and gravity acceleration.

$$
\begin{gathered}
g_{\text {zast }}=k \cdot g \\
g_{\text {zast }}=a_{\Sigma}=k \cdot g
\end{gathered}
$$

$a_{\Sigma} \quad-$ the sum of the acceleration components acting in the same direction.

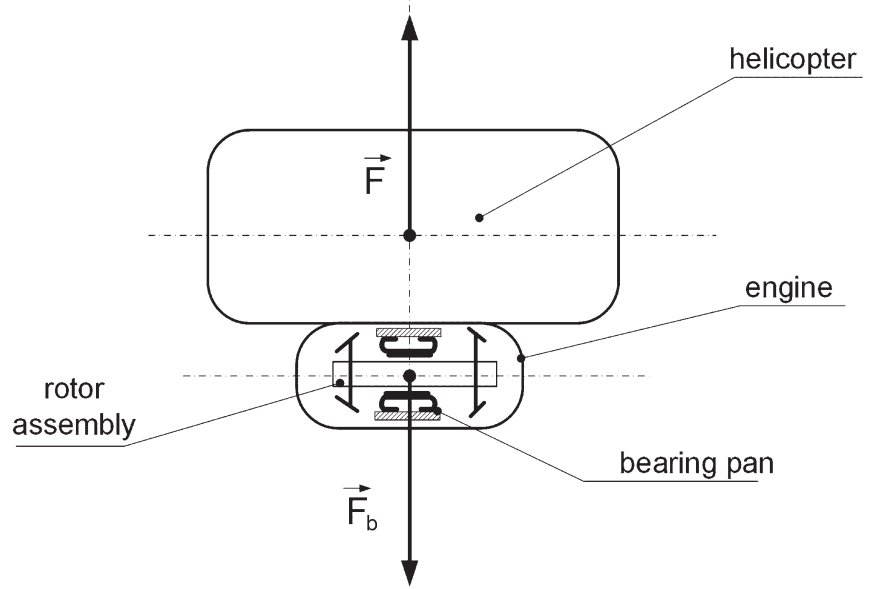

Fig. 15. Scheme of the helicopter accelerations impact on the rotor assembly in the drive system, own study

If the helicopter acts with $F$ force with a certain acceleration, then a shaft (rotor assembly), depending on the size of the mass, will act on the bearing pan with inertial force $F_{b}$ that has an opposite direction to the acceleration, as shown in Figure15:

$$
\begin{aligned}
& \vec{F}-m \vec{a}=0 \\
& \vec{F}_{b}=-m \vec{a} \\
& \vec{F}+\vec{F}_{b}=0
\end{aligned}
$$

To determine the value of overloading, the individual maneuvers should be analyzed in terms of acceleration values and the direction of their actions, and also the kind of loaded bearings (axial, radial). During the jump up maneuver from all of the forces shown in Figure11 and table 4, only forces shown below occurs:

$R_{A 1}^{y} / R_{B 1}^{y} \quad$ - gravity force of the rotor assembly, 
$R_{A 2}^{y} / R_{B 2}^{y}$ - force caused by acceleration during the jump up maneuver,

$R_{B 1}^{x} \quad$ - aerodynamic gas force.

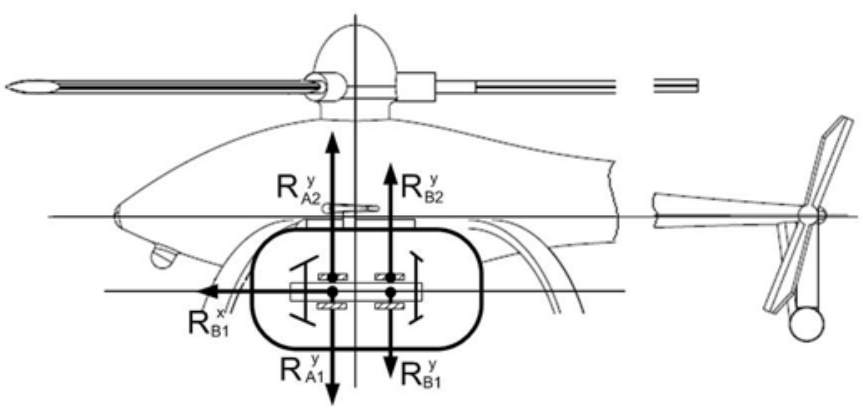

Fig. 16. Scheme of load of bearing nodes during a maneuver jump up, own study

It is assumed that the elements of the compressor drive unit assembly are structured in such way that they make an axial aerodynamic forces to equilibrate. This fact causes force equal zero, but the gravity forces are equal (based on static calculations):

$$
\begin{aligned}
& R_{A 1}^{y}=P_{A 1}^{s t}=5.638 N \\
& R_{B 1}^{y}=P_{B 1}^{s t}=1.631 N
\end{aligned}
$$

The forces of inertia $\mathrm{R}_{\mathrm{A} 2}^{\mathrm{y}} / \mathrm{R}_{\mathrm{B} 2}^{\mathrm{y}}$ caused by acceleration during the maneuver are multiplication of the respective gravity forces, where the multiplication coefficient is the value of the overload. Based on the performed analysis, the maximum acceleration value was equal $\mathrm{a}_{\max }=19.92 \mathrm{~m} / \mathrm{s}^{2}$, what gives as follow:

$$
\begin{gathered}
a_{\Sigma}=a_{\max }+g \\
a_{\Sigma}=29.73 m / s^{2}
\end{gathered}
$$

According to equation (28) and (29), the $k$ coefficient is:

$$
\begin{gathered}
k=\frac{a_{\sum}}{g}=3.03 \\
P_{A 1}^{y d y n}=k \cdot P_{A 1}^{s t}=17.1 \mathrm{~N}
\end{gathered}
$$

During the jump down maneuver, such a forces occurs:

$$
\begin{aligned}
& R_{A 1}^{y} / R_{B 1}^{y} \quad-\text { gravity force of rotor assembly, } \\
& R_{A 2}^{y} / R_{B 2}^{y} \quad \text { - force caused by acceleration during the jump } \\
& \text { down maneuver, } \\
& R_{B 1}^{x} \quad-\text { aerodynamic gas force. }
\end{aligned}
$$

It is assumed that the elements of the compressor drive unit are structured in such way that they make an axial aerodynamic forces to equilibrate. This fact causes $\mathrm{R}_{\mathrm{B} 1}^{\mathrm{x}}$. force equal zero, but the gravity forces are equal (based on static calculations):

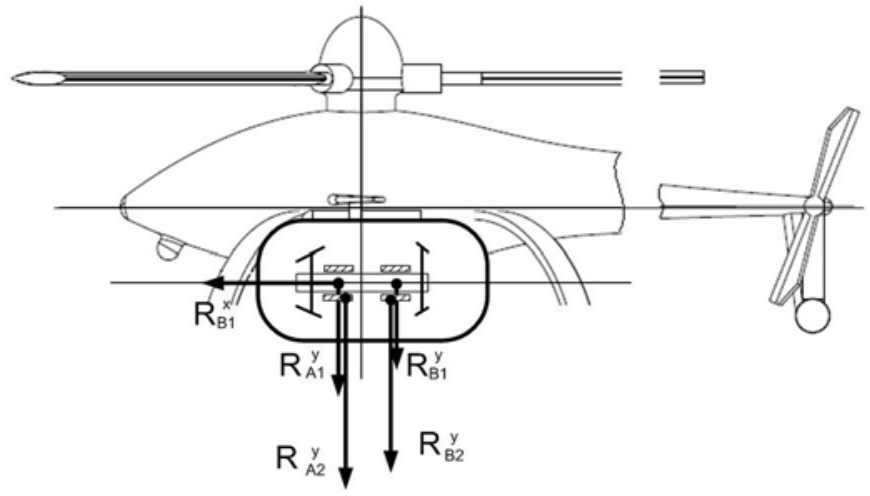

Fig. 17. Scheme of load of bearing nodes during a maneuver jump down, own study

$$
\begin{aligned}
& R_{A 1}^{y}=P_{A 1}^{s t}=5.638 N \\
& R_{B 1}^{y}=P_{B 1}^{s t}=1.631 N
\end{aligned}
$$

The forces of inertia $\mathrm{R}_{\mathrm{A} 2}^{\mathrm{y}} / \mathrm{R}_{\mathrm{B} 2}^{\mathrm{y}}$ caused by acceleration during the maneuver are multiplication of the respective gravity forces, where the multiplication coefficient is the value of the overload. Based on the performed analysis, the maximum acceleration value was equal $\mathrm{a}_{\max }=5,85 \mathrm{~m} / \mathrm{s}^{2}$, what gives as follow:

$$
\begin{gathered}
a_{\Sigma}=a_{\max }-g \\
a_{\Sigma}=-3.96 \mathrm{~m} / \mathrm{s}^{2}
\end{gathered}
$$

According to equation (28) and (29), the $k$ coefficient is:

$$
\begin{gathered}
k=\frac{a_{\sum}}{g}=-0.4 \\
P_{A 1}^{y d y n}=k \cdot P_{A 1}^{s t}=-2.26 \mathrm{~N}
\end{gathered}
$$

\section{Conclusion}

The performed analysis of maximum load states of the bearing nodes in the rotor assembly shows, that during a maneuver jump up and jump down radial bearing $\mathrm{A}$ is more loaded than bearing $\mathrm{B}$. The maximum value of the load force acting on radial bearings node $\mathrm{A}$ is $\mathrm{P}_{\mathrm{p}}=17.1 \mathrm{~N}$ and in the case of axial bearings, acting force is always equal zero, in the case that the working components of the compressor drive unit are structured such that they create an axial aerodynamic forces to equilibrate. It is important to note, that the resulting values refer only to one maneuver jump up and jump down. Therefore, these values will be confronted with the values obtained during other maneuvers such as acceleration and deceleration, deceleration before the attack, tight curve and return to the target. However, they will be the subject of the future work. Statement of comprehensive analysis of possible loads will allow the use of the compressor drive unit of turbine engine in normal conditions, while extending the service life.

\section{References}

1. Dudziak J. Mass analysis of profitability of use piston and turbine engines for driving light helicopters. Transactions of the Institute of Aviation 2013; 232: 15-23, http://dx.doi.org/10.5604/05096669.1106587.

2. Dudziak J. Analiza numeryczna dynamiki współdziałania schładzacza spalin z silnikiem napędowym w ekstremalnych lotach śmigłowca. Lublin University of Technology, diploma thesis, 2011. 
3. Fijałkowski S. Materiały naukowe na zebranie środowiskowe Sekcji Podstaw Eksploatacji PAN. Lublin: Lublin University of technology Publishing, 1988.

4. Guła P, Gorecki T. Design and development of a Polish unmanned rotorcraft ilx-27. Transactions of the Institute of Aviation 2013; 232: 3949, http://dx.doi.org/10.5604/05096669.1106664.

5. Giemza B, Nowiński E, Domański M. Gas-dynamic foil bearings application in high-speed turbines. Journal of KONBiN 2013; 3,4 (27,28): 100-101.

6. Hajduk J, Sabak R. Flight of the unmanned helicopter ilx-27 - some selected issues. Journal of KONBiN 2013; 1(25): 45-58.

7. Heshmat H, Shapiro W, and Gray S. Development of Foil Journal Bearings for High Load Capacity and High Speed Whirl Stability. ASME Journal of Lubrication Technology 1982; 104(2): 149-156, http://dx.doi.org/10.1115/1.3253173.

8. Heshmat H. Operation of Foil Bearings Beyond the Bending Critical Mode. ASME Journal of Lubrication Technology 1999; $122(1): 192-198$.

9. Kazimierski Z., Krysiński J. Łożyskowanie gazowe i napędy mikroturbinowe. Warszawa: WNT, 1981.

10. Kazulo Z., Bereżański J. Sprawozdanie z prób w locie śmigłowca PZL Sokół dla określenia granicznych warunków eksploatacji w kontekście wymogów zastosowań specjalnych. WSK-Świdnik S.A. in cooperation with Aviation Institute 1999; 1LSP-36/367/2.

11. Konstantinesku W. N. Gazowaja smazka. Moscow: Maszinostrojenie, 1968.

12. Lee Y. B., Kim T. H., et al. Dynamic Characteristics of a Flexible Rotor System Supported by a Viscoelastic Foil Bearing. Journal of Lubrication Technology 2004; 37: 679-687, http://dx.doi.org/10.1016/s0301-679x(03)00013-6.

13. Magryta P., Majczak A. Diesel engine applicability in a light helicoter. Autobusy 2012; 4: 98-103.

14. Peng Z, Khonsari M. M. A Thermo-hydrodynamic Analysis of Foil Journal Bearings. ASME 2006; 128: 534.

15. Szejnberg S. A. et al. Opory skolrzenija s gazowoj smaskoj. Moscow: Maszinostrojenie, 1979.

16. Śmiech A. Analiza możliwości zastosowania łożysk gazowych w sprężarce doładowującej typu Comprex. Lublin University of Technology, diploma thesis, 2002.

17. Wendeker M., Siadkowska K., Magryta P., Czyz Z., Skiba K. Optimal Diesel Engine Technology Analysis Matching the Platform of the Helicopter. International Journal of Mechanical, Industrial Science and Engineering 2014; 8(5): 790-794.

Mirosław WENDEKER

Zbigniew CZYŻ

Department of Thermodynamics, Fluid Mechanics and

Aviation Propulsion Systems

Lublin University of technology

Nadbystrzycka 36, 20-618 Lublin, Poland

E-mail:m.wendeker@pollub.pl, z.czyz@pollub.pl 